\title{
Penerapan Model Pembelajaran Problem Based Learning untuk Meningkatkan Motivasi Belajar IPA
}

\author{
Ni Putu Suari* \\ Sekolah Dasar Negeri 1 Darmasaba.
}

\section{A R T I C L E I N F O}

Article history:

Received 20 May 2018

Received in revised form 6 June 2018

Accepted 10 July 2018

Available online 20 August 2018

\section{Kata Kunci:}

model pembelajaran

Problem Based Learning,

motivasi belajar IPA

Keywords: problem based learning, students' motivation

\begin{abstract}
A B S T R A K
Penelitian ini bertujuan untuk mengetahui peningkatan motivasi belajar IPA siswa kelas VI semester I di SD 1 Darmasaba tahun pelajaran 2016/2017 setelah diterapkannya model pembelajaran Problem Based Learning. Jenis penelitian ini adalah penelitian tindakan kelas (PTK) dengan subjek penelitian adalah siswa kelas VI semester I yang berjumlah 25 orang siswa. Data motivasi belajar IPA siswa dikumpulkan dengan kuesioner. Data yang diperoleh dianalisis menggunakan analisis statistik deskriptif. Berdasarkan hasil analisis data, pada siklus I rerata motivasi belajar IPA siswa kelas VI semester I di SD 1 Darmasaba setelah mengikuti pembelajaran dengan menerapkan model pembelajaran Problem Based Learning sebesar 104,96 dan berada pada kategori tinggi. Persentase ketuntasan klasikalnya adalah $76 \%$. Pada siklus II rerata motivasi belajar IPA siswa kelas VI semester I di SD 1 Darmasaba setelah mengikuti pembelajaran dengan menerapkan model pembelajaran Problem Based Learning meningkat yakni menjadi 121,68 dan berada pada kategori sangat tinggi. Persentase ketuntasan klasikalnya adalah 96\%. Berdasarkan hasil tersebut dapat disimpulkan bahwa model pembelajaran Problem Based Learning secara efektif mampu meningkatkan motivasi belajar IPA siswa.
\end{abstract}

\section{A B S T RA C T}

This research aimed at implementing problem based learning model to improve students' learning motivation in science. The subjects of this classroom action research were 25 students in Grade VI, semester I, academic year 2016/2017 in SD No.1 Darmasaba. Students' interests were collected using questionnaire and analyzed descriptively. Result showed that after implementing problem based learning model in Cycle I, students' motivation reached 104.96 which was categorized as highly motivated. Students' classical completeness was $76 \%$. After Cycle II, students' motivation reached 121.68 which were categorized as very highly motivated. Students' classical completeness were $96 \%$. Thus, it is concluded that problem based learning model can be implemented to improve students' motivation in science. 


\section{Pendahuluan}

Peranan pendidikan pada Era Globalisasi saat ini sangatlah penting, dimana pendidikan menjadi faktor utama dalam meningkatkan kualitas sumber daya manusia yang lebih baik, oleh karena itu saat ini banyak metode/strategi pembelajaran, fasilitas belajar yang bermunculan dengan tujuan untuk menarik motivasi belajar siswa. Upaya - upaya yang dilakukan pemerintah sudah merambah hampir ke semua komponen pendidikan seperti penambahan jumlah buku-buku pelajaran, peningkatan kualitas guru, pembaharuan kurikulum dan peningkatan kualitas pembelajaran yang mencakup pembaharuan dalam model, metode, pendekatan dan media guna mengoptimalkan kualitas pembelajaran. Rendahnya hasil belajar IPA saat ini sangat banyak dikarenakan oleh kurangnya pemahan dan keterampilan proses siswa untuk menemukan dan mengungkapkan suatu permasalahan itu sendiri dan hal tersebut dikarenakan minimnya fasilitas dan perlengkapan siswa untuk melakukan praktek IPA secara langsung dan hanya berpatokan pada buku ataupun penjelasan guru saja.

Pembelajaran Ilmu pengetahuan Alam, terutama di tingkat SD sebaiknya mengacu pada tingkat perkembangan siswa pada masa itu, yaitu tahap operasional konkret dan operasional formal. Menurut Piaget, belajar akan menjadi efektif bila kegiatan belajar sesuai dengan tingkat perkembangan intelektual pebelajar, dan tidak ada belajar tanpa perbuatan. Hal ini disebabkan perkembangan intelektual siswa dan emosinya dipengaruhi langsung oleh keterlibatannya secara fisik dan mental dengan lingkungannya. Oleh karena itu pembelajaran Ilmu Pengetahuan Alam di pendidikan dasar, hendaknya mengupayakan pembelajaran melalui aktivitas konkret, dengan menghadirkan fenomena alam dalam setiap pembelajaran. Fenomena alam dalam proses pembelajaran identik dengan lingkungan yang digunakan sebagai sumber belajar untuk memahami materi-materi yang erat kaitannya dengan kehidupan seharihari. Lingkungan merupakan sumber belajar yang kaya dan menarik untuk siswa. Lingkungan manapun bisa menjadi tempat yang menyenangkan bagi siswa .Pembelajaran dengan media lingkungan sangat efektif diterapkan di sekolah dasar. Hal ini relevan dengan tingkat perkembangan intelektual usia sekolah dasar (7-11 tahun) berada pada tahap operasional konkret.

Setiawan, dkk (2007) menyatakan bahwa Lingkungan dan alam sekitar bisa memberikan kegembiraan kepada siswa. Itu dapat di lihat di lapangan, di kebun, di pekarangan rumah bahkan di tempat- tempat yang kurang bersih. Di sekolah, siswa juga harus didekatkan dengan alam. Secara naluriah siswa akan merasa gembira apabila dekat dengan alam. Selain berfungsi sebagai media bagi siswa, masih banyak lagi manfaat lain dari alam yang tak kalah pentingnya bagi perkembangan kejiwaan siswa. Alam juga dapat menumbuhkan kreatifitas siswa. Dengan memperoleh pengalaman langsung melalui alam, rasa ingin tahu dan semangat belajar siswa akan bertambah.

Namun pada kenyataanya di SD berdasarkan observasi yang telah dilakukan, dalam mata pelajaran IPA khususnya di kelas VI SD N 1 Darmasaba Tahun Pelajaran 2016/2017 kegiatan pembelajarannya masih dilakukan hanya dengan ceramah dan siswa pasif. Pembelajaran lebih ditekankan pada metode yang banyak diwarnai dengan ceramah, kurang menggunakan media serta masih berpusat pada guru. Hal ini mengakibatkan siswa kurang ikut berpartisipasi dalam kegiatan pembelajaran yang cenderung menjadikan siswa cepat bosan dan kurang berkonsentrasi pada saat belajar. Karena berbagai hal tersebut di atas mengakibatkan hasil belajar siswa kurang optimal terlihat dari belum tercapainya kriteria ketuntasan minimal (KKM).

Penanganan permasalahan seperti diuraikan di atas memerlukan suatu upaya praktis yang bertujuan memperbaiki proses pembelajaran ke arah yang lebih baik. Salah satu upaya yang dapat dilakukan adalah dengan penerapan model-model pembelajaran yang mengacu pada proses pembelajaran berpusat pada siswa. Salah satu model pembelajaran yang dapat diterapkan adalah model pembelajaran Prolem Based Learning. Model pembelajaran Prolem Based Learning adalah salah satu model pembelajaran yang sangat ideal diterapkan dalam pembelajaran IPA. Dengan topik IPA yang cukup luas dan desain tugas-tugas atau sub-sub topik yang mengarah pada kegiatan metode ilmiah, diharapkan siswa dan kelompoknya dapat saling memberi kontribusi berdasarkan pengalaman sehari-hari, (Rusman,2010:221).

Pembelajaran IPA tidak dapat hanya dipelajari melalui teori saja melaikan harus diimbangi dengan suatu percobaan dan praktek-praktek yang bertujuan untuk meningkatkan keterampilan proses siswa, tetapi masih banyak juga yang sering terjadi guru hanya memberikan penjelasan yang ada pada buku saja tanpa mementingkan praktek-praktek ataupun keterampilan proses siswa dalam memecahkan suatu permasalahan yang dapat meningkatkan kemampuan siswa. Dalam memecahkan suatu permasalahan untuk mencapai hasil yang maksimal diperlukan suatu model pembelajaran yang tepat agar PBM khususnya mata pelajaran IPA tersebut dapat mencapai hasil yang maksimal dan dari model-model pembelajaran yang ada PBL lah yang paling tepat karena model pembelajaran PBL dapat meningkatkan 
kreativitas dan memancing pengetahuan siswa untuk memecahkan permasalah dengan memalui suatu keterampilan proses.

Pembelajaran yang dapat dikatakan optimal adalah pembelajaran dimana guru tidak hanya menjelaskan saja tetapi siswa yang harus lebih aktif untuk mencari tahu dan membangun sendiri pengetahuannya dan peran guru sebagai fasilitator dan motivator, hal tersebut bertujuan agar siswa menjadi lebih mandiri/terampil dan aktif pada saat pembelajaran berlangsung. Untuk menciptakan pembelajaran yang optimal harus memikirkan pendekatan dan media yang sesuai dengan materi. Tugas utama guru adalah menyelenggarakan kegiatan pembelajaran yang memungkinkan terjadinya interaksi secara optimal antara siswa dengan siswa ataupun siswa dengan guru atau sebaliknya. Bagaimanapun bagus dan idealnya pendidikan, bagaimanapun lengkapnya sarana dan prasarana pendidikan tanpa diimbangi dengan kemampuan guru dalam mengimplementasikannya, maka proses pembelajaran akan kurang bermakna. Guru diberikan kebebasan untuk memanfaatkan berbagai pendekatan dan metode pembelajaran yang dapat menumbuhkan minat, keterampilan proses,perhatian, dan keaktifan siswa sehingga proses pembelajaran menjadi lebih bermakna. (Depdiknas, 2006:2)

Joyce (dalam Trianto, 2007:5) mengemukakan bahwa model pembelajaran adalah suatu kerangka konseptual yang melukiskan prosedur yang sistematis dalam mengorganisasikan pengalaman belajar untuk mencapai tujuan tertentu dan berfungsi sebagai pedoman bagi perancang pembelajaran dan para pengajar dalam merencanakan dan melaksanakan proses pembelajaran. Penerapan ajaran tut wuri handayani juga merupakan wujud nyata yang bermakna bagi manusia masa kini dalam rangka menjemput masa depan. Salah satu model pembelajaran yang dapat diterapkan yaitu model Problem Based Learning (Pembelajaran Berbasis Masalah).

Model Problem Based Learning merupakan model pembelajaran yang melibatkan siswa dalam memecahkan masalah nyata. Model ini menyebabkan motivasi dan rasa ingin tahu menjadi meningkat. Model PBL juga menjadi wadah bagi siswa untuk dapat mengembangkan cara berpikir kritis dan keterampilan berpikir yang lebih tinggi (Gunantara,2014). Problem Based Learning (Pembelajaran Berbasis Masalah) memberikan kesempatan kepada siswa untuk mengungkapkan gagasan secara eksplisit, memberi pengalaman yang berhubungan dengan gagasan yang telah dimiliki siswa. Sehingga siswa terdorong untuk membedakan dan memadukan gagasan tentang fenomena yang menantang. Model pembelajaran PBL ini mendorong siswa dapat berfikir kreatif, imajinatif, refleksi, tentang model dan teori, mengenalkan gagasan- gagasan pada saat yang tepat, mencoba gagasan baru, mendorong siswa untuk memperoleh kepercayaan diri. Problem Based Learning (PBL) adalah suatu proses pembelajaran yang diawali dari masalah-masalah yang ditemukan dalam suatu lingkungan pekerjaan (Muhson, 2009).

Berdasarkan pemaparan di atas, maka dalam penelitian ini mengambil judul tentang Penerapan Model Pembelajaran Problem Based Learning Untuk Meningkatkan Motivasi belajar IPA Siswa Kelas VI Semester I di SD 1 Darmasaba Tahun Pelajaran 2016/2017.

\section{Metode}

Penelitian ini dilaksanakan di SD No 1 Darmasaba semester I tahun pelajaran 2016/2017. Penelitian ini dilaksanakan dari bulan Agustus sampai Oktober 2016. Subjek penelitian ini adalah siswa Kelas VI Semester I SD 1 Darmasaba Tahun Pelajaran 2016/2017 pada tahun ajaran 2016/2017 dengan jumlah keseluruhan 25 siswa. Adapun objek penelitian ini adalah motivasi belajar siswa Kelas VI Semester I SD 1 Darmasaba Tahun Pelajaran 2016/2017 dengan model pembelajaran Problem Based Learning $(P B L)$.

Penelitian tindakan kelas dirancang dalam beberapa siklus, dengan masing-masing siklus terdiri dari 3 kali pertemuan. Rancangan penelitian ini mengacu berdasarkan model yang dikemukakan Kemmis dan MC Taggart (Agung, 2005:91) "Dalam model PTK ini ada empat tahapan pada siklus penelitian, keempat tahapan tersebut terdiri dari: perencanaan, tindakan, observasi/evaluasi, dan refleksi". Pelaksanaan penelitian ini dilakukan dalam bentuk siklus yang dapat digambarkan dalam model seperti gambar sebagai berikut. 


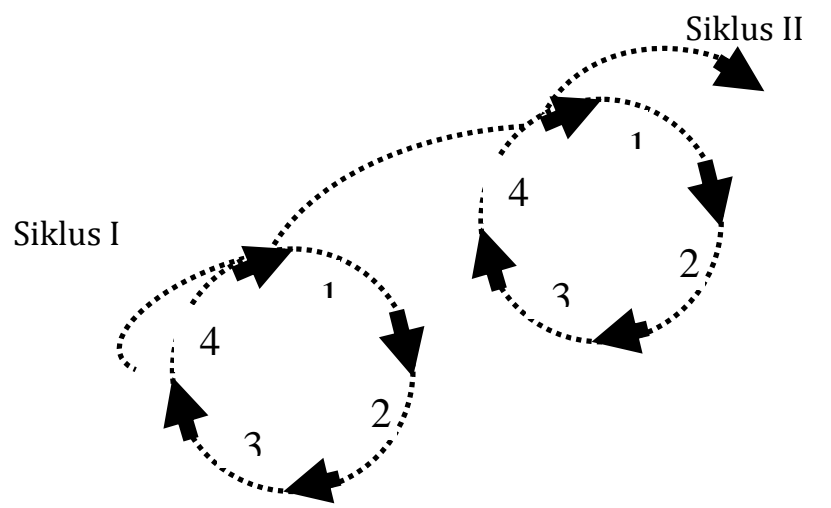

Keterangan:

1. Perencanaan

2. Tindakan

3. Obsevasi/evaluasi

4. Refleksi

Gambar 1. Model PTK dalam Dua Siklus (Agung, 2005)

Tiap siklus mengikuti langkah yang sama seperti berikut ini.

Pertama, Perencanaan merupakan hasil refleksi awal terhadap permasalahan proses dan hasil belajar di kelas yang menjadi objek penelitian, ditetapkan alternatif tindakan dalam kelas yang dapat meningkatkan motivasi belajar siswa. Dalam perencanaan ini dilaksanakan kegitan yaitu mengkaji atau telaah kurikulum, membuat rencana pembelajaran (RPP), menyiapkan materi pembelajaran dari berbagai buku sumber, dan menyiapkan media pembelajaran. Kedua, Dalam pelaksanaan tindakan ini disesuaikan dengan jadwal pelajaran di sekolah yakni menerapkan model pembelajaran Problem Based Learning (PBL) dalam mata pelajaran IPA untuk meningkatan motivasi belajar siswa. Adapun langkah-langkah yang dilakukan dalam pelaksanaan tindakan kelas antara lain: menjelaskan pokok bahasan yang akan diajarkan pelaksanaan tindakan dengan prosedur yang ada pada RPP. Ketiga, pada Observasi/Evaluasi yang perlu diperhatikan adalah Selama proses pembelajaran berlangsung dilakukan pengamatan melalui minat siswa terhadap yang didapatkan melalui keaktifan siswa, semangat siswa dalam mengikuti proses pembelajaran, dan Pada akhir pembelajaran dilakukan penilaian motivasi belajar siswa dengan memberikan kuisioner pada akhir pembelajaran. Dan keempat, Refleksi merupakan kegiatan mengadakan perenungan terhadap motivasi belajar siswa yang telah dicapai setelah menerapkan model pembelajaran Problem Based Learning (PBL) pada mata pelajaran IPA.

Data yang dikumpulkan oleh peneliti adalah data yang mengenai motivasi belajar IPA siswa Kelas VI Semester I SD 1 Darmasaba Tahun Pelajaran 2016/2017. Adapun cara yang dapat dilakukan untuk mengumpulkan data mengenai motivasi belajar IPA siswa maka diperlukan metode pengumpulan data dengan menggunakan metode kuesioner.

Pada penelitian ini, teknik analisis data yang digunakan dalam penelitian tindakan kelas ini adalah dengan menggunakan teknik analisis deskriptif kuantitatif.

Menurut Agung (2014:144) "metode analis deskriptif kuantitatif adalah suatu cara pengolahan data yang dilakukan dengan jalan menyusun secara sistematis dalam bentuk angka-angka atau persentase mengenai suatu objek yang diteliti sehingga diperoleh kesimpulan umum".

Dalam penerapan metode analisis statistik deskriptif ini, data yang diperoleh dari hasil penelitian dianalisis dan disajikan ke dalam: a) menghitung angka rata-rata (Mean), b) menghitung median, c) menghitung modus. Mean, median modus dihitung dengan bantuan Microsoft excel.

Indikator keberhasilan pelaksanaan ini, berpedoman pada kriteria : rata-rata motivasi belajar siswa minimal pada kategori tinggi, dan ketuntasan klasikal sebesar $90 \%$.

\section{Hasil dan Pembahasan}

Model pembelajaran Problem Based Learning (Pembelajaran Berbasis Masalah) memberikan kesempatan kepada siswa untuk mengungkapkan gagasan secara eksplisit, memberi pengalaman yang berhubungan dengan gagasan yang telah dimiliki siswa. Sehingga siswa terdorong untuk membedakan dan memadukan gagasan tentang fenomena yang menantang. Model pembelajaran PBL ini mendorong siswa dapat berfikir kreatif, imajinatif, refleksi, tentang model dan teori, mengenalkan gagasan- gagasan pada saat yang tepat, mencoba gagasan baru, mendorong siswa untuk memperoleh kepercayaan diri.

Model pembelajaran ini sangat cocok diterapkan pada mata pelajaran IPA, karena pada pembelajaran IPA siswa dituntut aktif untuk berpikir kreatif, imajinatif dan yang lainnya. Kreativitas siswa sangat dituntut karena pada pembelajaran IPA materinya tidak bisa hanya dihafal, namun juga dipraktekkan atau melakukan praktikum. 
Berdasarkan penelitian yang telah dilakukan dengan menerapkan Model pembelajaran Problem Based Learning, didapatkan bahwa rerata Motivasi Belajar IPA siswa pada siklus I berada pada kategori tinggi dengan ketuntasan klasikal sebesar 76\%. Hasil ini menunjukkan bahwa indikator keberhasilan penelitian belum tercapai secara maksimal, dikarenakan ketuntasan klasikal siswa belum mencapai 90\%.

Belum tercapainya ketuntasan klasikal siswa disebabkan karena ada beberapa siswa yang kurang aktif dalam mencari pemecahan permasalahan yang dihadapinya saat proses pembelajaran. Terutama dalam hal membaca materi atau buku, padahal beberapa permasalahan ada jawabannya di materi buku yang mereka miliki. Rendahnya antusias siswa dalam membaca materi di buku, mengindikasikan motivasi belajar siswa belum optimal.

Berdasarkan penelitian yang sudah dilaksanakan pada siklus II, terlihat bahwa pembelajaran pada siklus II sudah berjalan lebih baik dari siklus I. Hal tersebut terbukti dari peningkatan rata-rata prestasi belajar siswa yang meningkat menjadi sangat tinggi dan ketuntasan klasikal siswa yang mencapai $96 \%$. Dan ini berarti bahwa indikator keberhasilan dalam penelitian ini sudah tercapai dengan maksimal.

Pada pembelajaran siklus II, siswa sudah mulai terbiasa membaca dari berbagai macam sumber, sudah terbiasa mencari point-point dari apa yang mereka pelajari, sudah terbiasa mencatat point-point dari materi pembelajaran, dan sumber belajar yang dimiliki siswa sudah lebih beragam. Hal ini menyebabkan siswa lebih mudah untuk memecahkan permasalahan-permasalahan yang diberikan atau dihadapinya saat proses pembelajaran.

Secara keseluruhan kendala yang dihadapi pada siklus II tidak terlalu nampak, namun hanya perlu pembiasaan yang lebih agar siswa mau membaca dari berbagai macam sumber sehingga wawasan siswa menjadi luas.

Untuk lebih jelasnya, peningkatan rata-rata dan ketuntasan klasikal siswa dari siklus I sampai siklus II dapat dilihat pada histogram berikut.

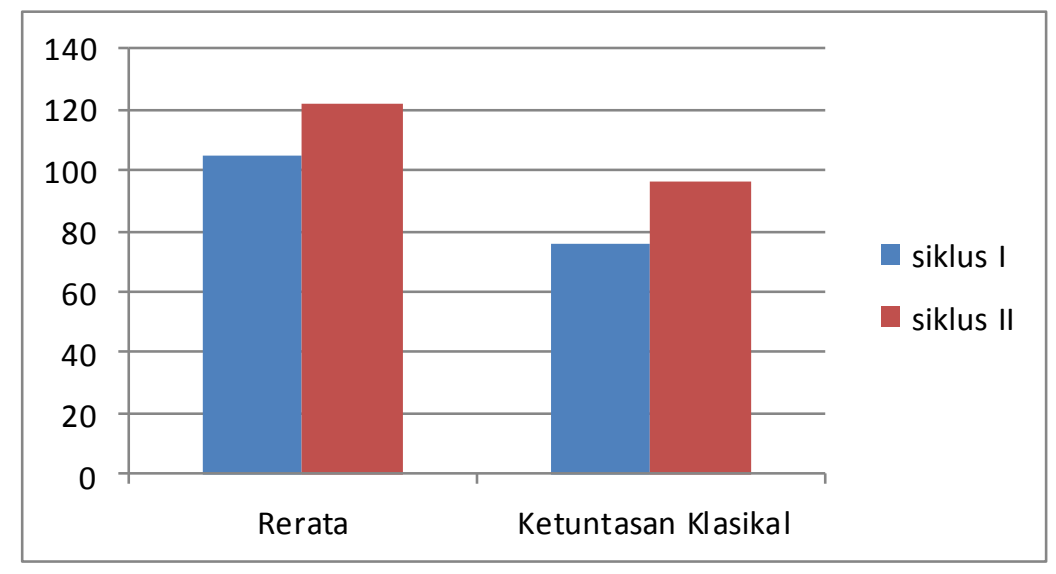

Gambar 2. Histogram Peningkatan Rata-Rata Dan Ketuntasan Klasikal Siswa dari Siklus I Sampai Siklus II

Hasil penelitian ini sejalan dengan hasil penelitian yang dilakukan oleh Wati, dkk (2015) yang berjudul Penerapan Model Pembelajaran Berbasis Masalah (PBM) Untuk Meningkatkan Hasil Belajar IPA Siswa di Kelas V SD Negeri Pasuruhan Pati. Dalam penelitiannya dinyatakan bahwa terdapat peningkatan ketuntasan belajar klasikal (kognitif) pada materi daur air yang cukup signifikan antara kondisi awal $(27,8 \%)$, siklus I $(66,7 \%)$, dan siklus II $(83,3 \%)$. Peningkatan hasil belajar juga didukung dengan peningkatan pengelolaan pembelajaran guru melalui penerapan model PBM mengalami peningkatan dari skor rata-rata siklus I 79,1\% (baik) menjadi 89,5\% (sangat baik) pada siklus II. Sedangkan hasil belajar (afektif dan psikomotor) juga mengalami peningkatan skor rata-rata siklus I 77\% (baik) menjadi 88,25\% (sangat baik) pada siklus II.

\section{Simpulan dan Saran}

Berdasarkan hasil penelitian yang telah didapatkan, dapat disimpulkan bahwa: penerapan model pembelajaran Problem Based Learning dapat meningkatkan Motivasi Belajar IPA siswa Siswa Kelas VI Semester I di SD 1 Darmasaba Tahun Pelajaran 2016/2017. Hal tersebut terlihat dari rata-rata yang didapat pada siklus I sebesar 104,96 dan meningkat pada siklus II menjadi 121,68. Sedangkan ketuntasan klasikal pada siklus I sebesar 76\% dan meningkat pada siklus II menjadi $96 \%$. 
Saran pada penelitian ini adalah sebagai berikut. (1) Siswa disarankan untuk rajin membaca berbagai macam sumber dalam belajar, sehingga siswa mendapatkan wawasan yang luas dan mampu memecahkan permasalahan-permasalahan yang dihadapinya dalam proses pembelajaran. (2) Guru disarankan untuk selalu memberikan wadah kepada siswa untuk mengembangkan keterampilan membaca dan menggunakan berbagai macam inovasi pembelajaran sehingga siswa merasa senang dan termotivasi dalam belajar. (3) Sekolah disarankan untuk selalu memberikan kebijakan-kebijakan yang mengarah kepada peningkatan sumber belajar maupun peningkatan SDM warga sekolah. (4) Peneliti lain disarankan untuk melakukan penelitian dengan menggunakan variabel yang lebih kompleks sehingga permasalahan dalam dunia pendidikan dapat diminimalkan.

\section{Daftar Rujukan}

Agung, A.A Gede. 2005. Metodelogi Penelitian Pendidikan. Singaraja: Fakultas Ilmu Pendidikan Institut Keguruan dan Keilmuan Negeri Singaraja.

Agung, A.A Gede. 2014. Metodologi Penelitian Pendidikan. Yogyakarta: Aditya Media Publising.

Depdiknas, 2006. Kurikulum Tingkat Satuan Pendidikan. Jakarta: Depdiknas.

Dewantara, D. (2014). Penerapan Model Pembelajaran Problem Based Learning Untuk Meningkatkan Aktivitas Dan Hasil Belajar Siswa Pada Pelajaran IPA (Studi Pada Siswa Kelas V SDN Pengambangan 6 Banjarmasin). Jurnal Paradigma. Volume 11 Nomor 2 Juli 2016, 41 - 44.

Dewi, K. A. P., Gading, I. K., \& Sudana, D. N. (2016). Pengaruh Model Pembelajaran Problem Based Learning $(P B L)$ Terhadap Hasil Belajar IPA Siswa Kelas IV SD. MIMBAR PGSD Undiksha, 4(1).

Giarti, S. (2015, November). Peningkatan Keterampilan Proses Pemecahan Masalah dan Hasil Belajar Matematika Menggunakan Model PBL Terintegrasi Penilaian Autentik Pada Siswa Kelas VI SDN 2 Bengle, Wonosegoro. In Prosiding Seminar Pendidikan Ekonomi dan Bisnis (Vol. 1, No. 1).

Gunantara,Gd, Md Suarjana, dan Pt. Nanci Riastini. 2014. Penerapan Model Pembelajaran Problem Based Learning Untuk Meningkatkan Kemampuan Pemecahan Masalah Matematika Siswa Kelas V. Jurnal Mimbar PGSD Universitas Pendidikan Ganesha. Vol. 2, No. 1.

Indah, N. (2015). Meningkatkan Prestasi Belajar IPA Materi Pokok Sumber Energi Gerak Melalui Penerapan Model Pembelajaran Problem Based Learning (PBL) Pada Siswa Kelas I.A SD Negeri 9 Kabangka Tahun Ajaran 2014/2015. 50 - 55.

Muhson, Ali. 2009. Peningkatan Minat Belajar Dan Pemahaman Mahasiswa Melalui Penerapan Problem Based Learning. Jurnal Kependidikan. Vol. 39, No. 2, Hal. 171-182.

Rusman. 2010. Model Model Pembelajaran. Bandung: Rajawali Pers,

Rahayu, P. I., Rosidin, U., \& Abdurrahman, A. (2015). Perbandingan Hasil Belajar Siswa antara Pembelajaran Menggunakan PBL dan Discovery Learning. Jurnal Pembelajaran Fisika, Vol. 3, No.5.

Setiawan, Denny. dkk. 2007. Komputer dan media pembelajaran. Jakarta: Universitas terbuka.

Suwandi, Y. (2015). Peningkatan Hasil Belajar IPA Tentang Ekosistem Melalui Metode Problem Based Learning Pada Siswa Kelas V Sekolah Dasar Kabupaten Tana Tidung. Jurnal Pendidikan Dasar Volume 6 Edisis 1 Mei 2015, 93 - 102.

Syafriana, D. (2016). Penerapan Model Problem Based Learning (Pbl) Dalam Pendekatan Saintifik Untuk Meningkatkan Hasil. Jurnal Inovasi Pendidikan Dan Pembelajaran Sekolah Dasar, 30 - 43.

Trianto. 2007. Model-model Pembelajaran Inovatif Berorientasi Konstruktivistik. Surabaya: Prestasi pustaka.

Wati, Nanik Istika, Sri Utaminingsih, dan Fina Fakhriyah. 2015. Penerapan Model Pembelajaran Berbasis 
Masalah (PBM) Untuk Meningkatkan Hasil Belajar IPA Siswa di Kelas V SD Negeri Pasuruhan Pati. Artikel. Prodi PGSD FKIP Unibersitas Muara Kudus.

Wahyudi, M. D. (2013). Meningkatkan Hasil Belajar Konsep Sifat - Sifat Cahaya Menggunakan Model Pembelajaran Problem Based Learning (PBL) Dan Word Square Pada Siswa Kelas V SDN Pemurus Dalam 7 Banjarmasin. Jurnal Paradigma Volume 8 Nomor 1 Januari - Juni 2013, 1 -7. 